\section{Subsidiering av malariamedikament}

\author{
Tilgangen på artemisininbasert kombinasjonsbehandling (ACT) økte \\ betydelig i fem av sju land etter oppstart av et subsidieringsprogram.
}

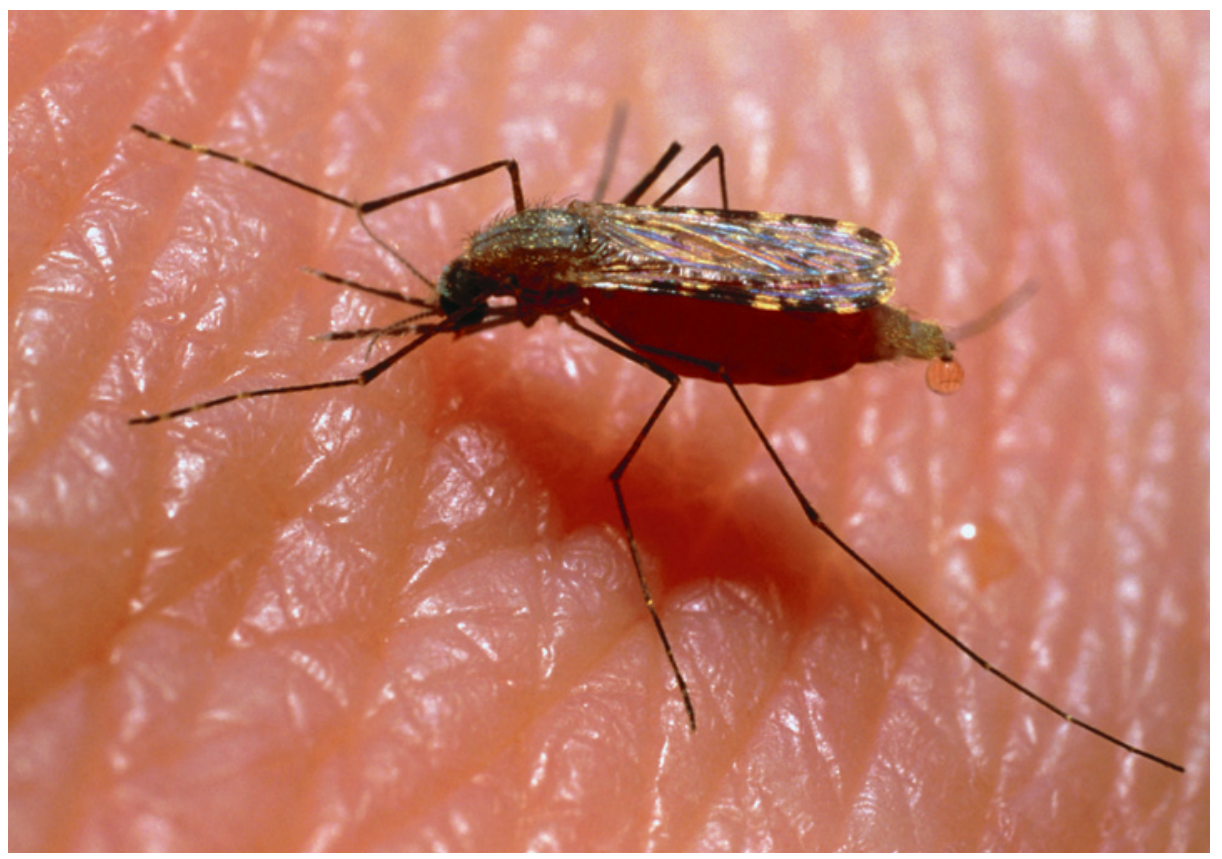

Illustrasjonsfoto Science Photo Library/NTB scanpix

Kombinasjonsbehandlingen anbefales av bl.a. WHO som førstelinjebehandling for ukomplisert malaria, men i 12 av de 16 endemiske landene i Afrika utgjør ACT mindre enn $60 \%$ av malariabehandlingen gitt til barn under fem år. Blant årsakene til dette er upålitelig tilførsel av og høye priser på denne behandlingen. Spesielt bekymringsfullt er bruken av artemisinin monoterapi, som kan virke resistensdrivende (1). I 2008 ble det opprettet et program med subsidiering av ACT, kalt Affordable Medicines Facility - malaria (AMFm).

AMFm består av forhandlinger for å redusere prisen på ACT, subsidiering via globale fond og promotering. Siden 2010 har et pilotprosjekt pågått i sju land: Ghana, Kenya, Madagaskar, Niger, Nigeria, Tanzania og Uganda. En uavhengig gruppe har nå evaluert effekten av programmet gjennom be$\mathrm{s} ø \mathrm{k}$ hos forhandlere av malariamedisiner, der de foretok spørreundersøkelser og dybdeintervjuer om omsetning og pris (1). Bortsett fra i Niger og på Madagaskar var det en

\section{Ubevisste valg i hippocampus}

\author{
Vi gjør av og til valg som tilsyne- \\ latende ikke bygger på erfaring. \\ I hippocampus oppstår assosia- \\ sjoner automatisk uten at vi er \\ oss det bevisst.
}

Vi foretar ofte raske og sikre valg selv om vi ikke har erfaring med alternativene. Det har vært foreslått at slike avgjørelser skyldes assosiasjoner til tidligere opplevelser. Amerikanske forskere har nå studert mulige mekanismer for denne typen assosiasjoner (1).

28 personer ble fulgt med funksjonell hjerneavbilding $i$ en studie der de ble eksponert for parvise visuelle stimuli. Halvparten av bildene ble så vist sammen med en pengeseddel. Når deltakerne deretter fikk valget mellom to avbildede gjenstander som ikke direkte hadde vært knyttet til belønning, valgte de den som i assosiasjonsfasen hadde vært vist sammen med gjenstanden som var blitt koblet til belønning etterpå. Denne avgjørelsesmekanismen skyldes aktivitet $i$ hippocampus.

- Hippocampus spiller en avgjørende rolle for en rekke kognitive prosesser som ikke bare har med hukommelse å gjøre, sier professor Anders M. Fjell ved Psykologisk institutt, Universitetet i Oslo. - En viktig funksjon for hippocampus er å finne regelmessigheter i miljøet og knytte disse sammen gjennom assosiasjoner. Det gjør det mulig å danne det vi kaller episodiske minner, en mekanisme som er utnyttet i denne undersøkelsen, sier han.

- Hippocampus bidro til at det ble dannet en assosiasjon mellom de to bildene deltakerne først ble eksponert for. Når det ene bildet senere ble assosiert med en belønning, oppsto det en indirekte assosiasjon også til det andre bildet. Spredningen av belønningsassosiasjoner kunne dermed skje ubevisst og påvirket naturlig nok senere valg, sier Fjell. - Alt $i$ alt mange velkjente prinsipper, men elegant satt sammen i denne studien.

\section{Trine B. Haugen}

trine.b.haugen@hioa.no

Tidsskriftet Affordable Medicines Facility-malaria (AMFm) on assured artemisinin-based combination therapies in seven countries: a before-and-after analysis of outlet survey data. Lancet 2012; 380: 1916-26.
Litteratur

1. Wimmer GE, Shohamy D. Preference by association: how memory mechanisms in the hippocampus bias decisions. Science 2012; 338: 270-3. 